Open Access

\title{
Interaction of Vietnamese teachers with a social constructivism-based primary science curriculum in a framework appropriate for a Confucian heritage culture
}

N. V. T. Hằng ${ }^{1^{*}}$, A. M.W. Bulte ${ }^{2}$ and A. Pilot ${ }^{2}$

* Correspondence:

hangnvt@hnue.edu.vn

${ }^{1}$ Hanoi National University of Education, 136 Xuan Thuy, Cau

Giay, Hanoi, Vietnam

Full list of author information is available at the end of the article

\begin{abstract}
This paper describes the perception of a social constructivist approach to teaching and learning among Vietnamese teachers in a Confucian heritage culture and the changes these teachers undergo through their interaction with a new science curriculum that was designed culturally appropriate. A framework of teacher professional development combining state-of-the-art knowledge on professional development and knowledge on curriculum design was adapted and applied to the establishment of a learning community with a facilitator and the teachers as critical co-designers. Through the spiral approach of the development programme, the teachers showed certain changes from a traditional way of teaching to a more social constructivist way of teaching. The teachers proposed concrete teacher activities that can be applied to complete the design of the curriculum and make it a better teaching guideline. The teachers perceived the challenges for applying the newly designed science curriculum in primary education in Vietnamese Confucian heritage culture. This study reveals opportunities to improve the curriculum design and emphasises the need to facilitate teachers in applying the designed curriculum into practice with the stress on the roles of teacher input and professional development.
\end{abstract}

Keywords: Teacher professional development, Interaction, Confucian heritage culture, Social constructivism-based curriculum, Science education 


\section{Tóm tắt}

Bài viết này trình bày nhận thức về hoạt động dạy học theo lối kiến tạo xã hội của các giáo viên Việt Nam trong nền văn hóa kế thửa Nho giáo và những thay đổi mà các giáo viên này có được qua quá trình tương tác với chương trình khoa học được thiết kế phù hợp với nền văn hóa. Một khung phát triển chuyên môn cho giáo viên với sự kết hợp những kiến thức mới nhất về nó đã được áp dụng, tạo nên một cộng đồng học tập mà ở đó người trợ giúp và giáo viên cùng đảm nhiệm vai trò người thiết kế. Qua cách tiếp cận vòng xoáy chôn ốc, chương trình phát triển chuyên môn này đã giúp các giáo viên có những thay đổi nhất định, chuyển từ cách dạy học truyền thống sang cách dạy học theo lối kiến tạo xã hội. Các giáo viên cũng đưa ra những đề xuất về những hoạt động cụ thể dành cho giáo viên để hoàn thiện thêm thiết kế chương trình và giúp cho nó trở thành một tài liệu dạy học tốt hơn. Các giáo viên cũng nhận thức được những thách thức sẽ gặp phải khi chương trình này được đưa vào vận dụng trong thực tế ở bậc tiểu học trong nền văn hóa kế thừa Nho giáo Việt Nam. Nghiên cứu này cũng chỉ ra được những hướng khả thi để cải tiến thiết kế chương trình và nhấn mạnh sự cần thiết của hoạt động hỗ trợ giáo viên trong quá trình thực hiện với sự coi trọng đầu vào của giáo viên cùng với các hoạt động phát triển chuyên môn dành cho họ.

\section{Introduction}

There are differences in teaching and learning across cultures and cultures have significant influences on education (Hofstede, Hofstede, and Minkov 2010; Nguyen et al. 2005). The how and what of education is strongly connected to the culture of the country. Despite having been increasingly applied in Western science education since the 1980s, it is challenging to implement a social constructivist approach (Beck and Kosnick 2006) in a Confucian heritage culture $(\mathrm{CHC})$. In a $\mathrm{CHC}$, teachers cannot easily be convinced of the effectiveness of active learning and student-centered pedagogical approaches which encourage students to actively construct knowledge through discussion, debate, and experimentation (Huang and Asghar 2016). Our earlier empirical study revealed that $\mathrm{CHC}$ teachers maintains a traditional approach of teaching and learning, in which the teacher is the central authority and students are passive in constructing and grasping knowledge (Hằng et $\mathrm{al}$. 2015). That study also showed that $\mathrm{a}$ $\mathrm{CHC}$ provided both hindering and fostering factors to the implementation of a social constructivist approach in primary science education (Hằng et al. 2015).

To address the problems of primary science education and to adapt Western educational theories to a $\mathrm{CHC}$, curriculum designs are needed that take characteristics of cultures into consideration (Nguyen et al. 2005; Örtenblad, Babur and Kumari 2012). A culturally appropriate pedagogy for visual communication students has been developed with the application of social constructivist theories for a CHC (Yam, Tan, and Lim 2016). Though such a pedagogy design was proved to enable CHC students to engage socially during the learning process with sufficient considerations of their cultural influences, there is a lack of information on how $\mathrm{CHC}$ teachers interact with the culturally appropriate design. The lack of knowledge on $\mathrm{CHC}$ teachers' interaction with a culturally appropriate curriculum has hindered researchers and educators from adequately evaluating such a curriculum design and from thoroughly assessing the curriculum implementation. It can hardly be expected that $\mathrm{CHC}$ teachers, who are unfamiliar with a 
social constructivist approach, could go smoothly with a new curriculum based on social constructivism and achieve intended educational goals unless they have opportunities to learn how to teach the curriculum. Any change or transformation in classroom practices ultimately rely on teachers (Borko 2004; Vos et al. 2010) and the interaction between teachers and the curriculum is needed to provide practical information which is useful for adjusting, improving, and disseminating the culturally appropriate curriculum for a wide use.

The aim of this study is therefore to fill the knowledge gap in research on the application of a social constructivist approach into primary science education with a curriculum designed appropriately with a $\mathrm{CHC}$. It adheres to the propositions that teachers play a crucial in translating the teaching materials into classroom practices and are the most influential factors in educational change (Duffee and Aikenhead 1992; Fullan 1991). Curriculum designers have to take into account the teachers' knowledge, believes, and skills in developing and implementing new curriculum, otherwise it is unlikely that the curriculum will be implemented as intended (Cotton 2006). The implementation of any new curriculum needs to be accompanied by a programme of Teacher Professional Development (PD) (Coll and Taylor 2012), which requires interaction between teachers and new curriculum, as a way to bridge the ideal curriculum and the operational curriculum (Van den Akker 2003). This study, as a part of a broader design-based research project on designing a social constructivism-based curriculum for primary science education in a $\mathrm{CHC}$, focuses on the interaction of Vietnamese teachers with a newly designed science curriculum (Hằng et al. 2016), thereby supporting the application of a social constructivist approach into nonWestern societies. It is an active response to the call for adopting and refining educational theories developed elsewhere to an Asian context (Örtenblad et al. 2012). By zooming into the interaction between Vietnamese teachers and the social constructivism-based science curriculum, this study contributes to knowledge base of teacher professional knowledge development regarding a CHC.

Teacher Professional Development and a Social Constructivism-Based Science Curriculum.

Teacher PD can be defined as the professional growth a teacher achieves as a result of gaining increased experience (Glatthorn 1995). When a new curriculum is drawn up by specialists, it is frequently left to the teachers to accommodate their knowledge, skills, and attitudes (Guskey 2002) in accordance with the new curriculum demands (Coenders, Terlouw and Dijkstra 2008). Teacher PD is often considered to produce a change in the competences of the teacher, which is seen as a complex process (Clarke and Hollingsworth 2002). Changes in teachers can occur in practice, as shown by changes in their attitudes and teaching activities. Changes also can occur in teachers' perceptions and beliefs about teaching and learning (Coenders et al. 2008). Many studies show that the actions of teachers in the classroom are largely determined by their knowledge and beliefs about teaching and learning (Loughran, Mulhall and Berry 2004; Van Driel, Verloop and De Vos 1998). They frequently do not implement curriculum materials that contradict their own ideas about content and how this content should be taught (Cotton 2006; Gees-Newsome 1999). To induce changes in teachers, a PD programme needs to help teachers feel sufficiently confident to apply their new knowledge and skills in practice (Stolk, Bulte, De Jong and Pilot 2011). 
A social constructivist approach has led to a new paradigm of Teacher PD (Le Cornu and Peters 2005) and influenced Teacher PD through changes in the concepts of both teacher and teaching. To define the constructivist approach for the new paradigm, we build on the work of Beck and Kosnik (2006), who described that a social constructivist approach helps learning more meaningful as it can involve the whole person: thought, emotion, and action. They defined a social constructivist approach on learning by 5 key features as below:

i) Learning is social;

ii) Knowledge is experience-based;

iii) Knowledge is constructed by learners;

iv) All aspects of a person are connected; and

v) Learning communities should be inclusive and equitable.

These features were used as the foundational ideas in designing a formal curriculum of primary school science that is culturally appropriate with a $\mathrm{CHC}$ to improve the primary science education (Hằng et $\mathrm{al}$. 2016). A curriculum framework with four learning phases was selected; these were labelled Engagement, Experience, Exchange, and Follow-up (Appendix 1). Based on the framework, three curriculum units were designed (Appendix 2) for teachers to enact in classroom practices. These units were: Air pressure, Plant roots, and $\mathrm{CO}_{2}$ Reactions. In order to track how $\mathrm{CHC}$ teachers could change towards a social constructivist approach through their interaction with the designed curriculum in a programme of Teacher PD, basic characteristics of a social constructivist teacher and a $\mathrm{CHC}$ teacher were needed to describe. The basic characteristics of a social constructivist teacher could be recognised in Brooks and Brooks (1993), in Le Cornu and Peters (2005), and in Watson (2001), and those of a CHC teacher were emerged in a detailed description by Hằng et al. (2015). The basic characteristics of a social constructivist teacher and of a traditional $\mathrm{CHC}$ teacher were presented in Table 1.

In the characteristics of a social constructivist teacher, open-mindedness is an attitude prerequisite for teaching (Dewey 1933). It is defined as an active desire to listen to more than one side or perspective on an issue. In this study, openmindedness is perceived as teachers' not judging students' answers based on a

Table 1 Basic characteristics of a social constructivist teacher and of a traditional $\mathrm{CHC}$ teacher

\begin{tabular}{|c|c|c|c|}
\hline Category & Item & Social constructivist teacher & Traditional CHC teacher \\
\hline \multirow[t]{2}{*}{ 1. Attitude } & a & Being open-minded & $\begin{array}{l}\text { Tending to be closed-minded by teaching } \\
\text { for "correct" answers }\end{array}$ \\
\hline & $b$ & Being friendly and equitable & Maintaining a superior role \\
\hline \multirow[t]{4}{*}{ 2. Activity } & a & Encouraging students to engage in inquiry & $\begin{array}{l}\text { Encouraging students to do listening- } \\
\text { reproducing activities }\end{array}$ \\
\hline & $b$ & $\begin{array}{l}\text { Providing time and space for students to } \\
\text { carry out self-regulated learning }\end{array}$ & Imposing knowledge on students \\
\hline & c & $\begin{array}{l}\text { Promoting social interactions among } \\
\text { students }\end{array}$ & $\begin{array}{l}\text { Adhering to one-way teacher-student } \\
\text { interaction }\end{array}$ \\
\hline & $d$ & $\begin{array}{l}\text { Seeking elaboration of students' initial } \\
\text { responses }\end{array}$ & Asking for single answers \\
\hline
\end{tabular}


standard of "correct or incorrect," but in a neutral way, accepting students' initiatives and metaphors, allowing students' responses to determine the direction of lessons and a shift in instructional strategies, and encouraging students to ask questions (Brooks and Brooks 1993; Watson 2001). In addition, it is used to indicate flexibility in teaching with regard to teacher roles and use of materials (Anderson 1996).

Being friendly and equitable is a necessary attitude for a social constructivist teacher, who is considered an advanced learner (Vygotsky 1978) who facilitates students' learning by negotiating (Hand, Treagust and Vance 1997), rather than a person who transmits factual knowledge to students and considers them as empty vases. In this sense, the friendliness in teaching attitudes is also supported by the feature of equitable learning communities in a social constructivist approach (Beck and Kosnik 2006). In this study, the teacher attitude of friendliness and equality is perceived as a looselycontrolled learning environment that teachers create to support students' involvement in learning freely and enthusiastically.

The teaching activities of a) encouraging students to engage in inquiry, b) providing time and space for students to carry out self-regulated learning, c) promoting social interaction among students, and d) seeking elaboration of students' initial responses (Category 2, Table 1) reflect the neutral roles of a social constructivist teacher as an encourager, a facilitator, and a coach for student learning (Anderson 1996; Beck and Kosnick 2006). Along with the characteristics of attitudes, the characteristics of the activities of the social constructivist teacher are considered as necessary for the implementation of the designed formal curriculum in science classrooms in a $\mathrm{CHC}$.

\section{Research context}

Vietnamese Confucian heritage culture

The study is situated in Vietnam, a country which has been deeply influenced by Confucianism for hundreds of years under cultural exchanges with China, especially in the period Vietnam was constrained by China about more than one thousand years ago (Nguyen et al. 2005; Thêm 1997). The following features are emerged in studies of many researchers, i.e. Berthrong and Berthrong (2000), Đạm (1994), and Thêm (1997), that can be used to briefly characterise Vietnamese CHC:

a. The collectivist root. Like other $\mathrm{CHC}$ countries, such as China, Taiwan, Japan, Korea, and Singapore, Vietnam has characteristics of a collectivist society with an agriculture-rooted culture that requires individuals to live a settled life with a fixed residence and value collectivity and solidarity as well.

b. The harmony and stability preference as a cultural and human value. Harmony is supported and recommended by Confucianism to help individuals obtain a consensus that can lead to a common peace and a stable life. Vietnamese individuals prefer to remain stable and in harmony with natural and social environments.

c. The virtue focus. Benevolence, righteousness, civility, knowledge, and loyalty are strongly stressed by Confucianism. Traditionally, in Vietnam, the cultivation of 
virtue is emphasised with the aim that the individual be a good person, and personal interests of $I$ should be limited to the interests of We.

d. The support of hierarchical order. Confucianism stresses a hierarchical order with its core objective of building a stable and well-ordered society. In Vietnam, hierarchical relationships are manifested by respect for age, position and family background.

e. The family value. Confucianism considers family to be a foundation community from which societal communities are expanded. In Vietnam, individuals are required to keep the family at the centre of their life and family relationship is often regarded to be more valuable than the law of the land.

f. The emphasis on theoretical knowledge. Theoretical knowledge in ancient classics was appreciated by Confucius and considered universally correct in $\mathrm{CHC}$.

Traditionally, in Vietnam, theoretical knowledge is considered as one of complementary aspects of the ideal person and the full knower [trên thông thiên văn dưới tường địa lí].

\section{Primary science education in Vietnam}

Primary science education in Vietnam is integrated into primary education that emphasises the mission of training students to be future labourers who have the necessary knowledge, skills, and attitudes to cope with the rapid changes of modern times and to contribute to the industrialisation of the country (Hoan 2002). The primary science curriculum in Vietnam is centralised and authorised by the Ministry of Education and Training. The current curriculum has been in use since the curriculum reform began in the year 2000. Science is a compulsory subject taught in all levels of primary education from Grade 1 (students aged 6) to Grade 5 (students aged 10). From Grade 1 to Grade 3, science is integrated into the subject called Nature and Society. From Grade 4 to Grade 5, science stays separate in the subject named Science. Science lessons are planned to last around $35 \mathrm{~min}$. They are often taught by class teachers who have to teach most of the subject areas.

Despite the curriculum reform and calls for innovating teaching and learning methods, it was found that the implementation of a social constructivist approach remains a low extent in primary science education in Vietnam (Hằng et al. 2015). This can be described shortly as:

- Teaching and learning was textbook-based and teacher-centred;

- Lessons were focused on factual knowledge;

- Reproduction of knowledge directly taught by the teacher;

- Hands-on complex tasks were absent;

- Students' personal aspects were discounted; and

- Hierarchical interactions remained in science classroom practices.

These are considered as the problems that need to address in order to enhance the quality of primary science education in Vietnam.

\section{Research question}

Based on the arguments above, this study aims to answer the following research question: 
In a programme of Teacher PD, how do Vietnamese teachers interact with a primary science curriculum that is based on a social constructivist perspective and made appropriate for a $\mathrm{CHC}$ ?

To answer this research question, three sub-questions were formulated:

1. What changes are there in the attitudes and activities of the teachers in classroom practices through their interaction with the designed curriculum appropriate for a $\mathrm{CHC}$ ?

2. How do the teachers perceive the designed curriculum appropriate for a CHC?

3. What do the teachers perceive as major challenges to the implementation of the designed curriculum appropriate for a $\mathrm{CHC}$ ?

\section{Research strategy}

The programme of Teacher PD was adapted from a framework for empowering teachers to teach innovative units (Stolk et al. 2012). The PD programme was also inspired by a lesson study approach and a collaborative work setting for $\mathrm{CHC}$ teachers to improve their class instruction (Lee 2008). Accordingly, three main phases were chosen for the $\mathrm{CHC}$ teachers in this study:

Phase 1 - Preparation for teaching the designed curriculum units. This phase has four functions:

(a). Connect to the views of individual teachers on a social constructivist approach to science education.

(b).Let teachers discover differences and similarities between their views on the social constructivism-based curriculum and curriculum units and their views on their conventional curriculum.

(c).Let teachers explore strategies for teaching the social constructivism-based curriculum units.

(d).Provide an opportunity for teachers to elaborate their specific teaching activities for the new curriculum units and co-design science lessons.

Phase 2 -Teaching and observing the science lessons. This phase has a single function:

(e). Provide teachers with an opportunity to apply knowledge of the designed formal curriculum to classroom practice and to acquire practical knowledge of the designed curriculum.

Phase 3 - Reflection on teaching activities and effects on students. This phase has two functions:

(f). Give teachers an opportunity to reflect on their teaching experiences.

(g).Evaluate the designed curriculum in terms of supporting the learning of science.

These phases were carried out in a spiral process in which iterative sub-phases were accomplished, creating a framework of PD (Fig. 1). This programme combined state-of- 


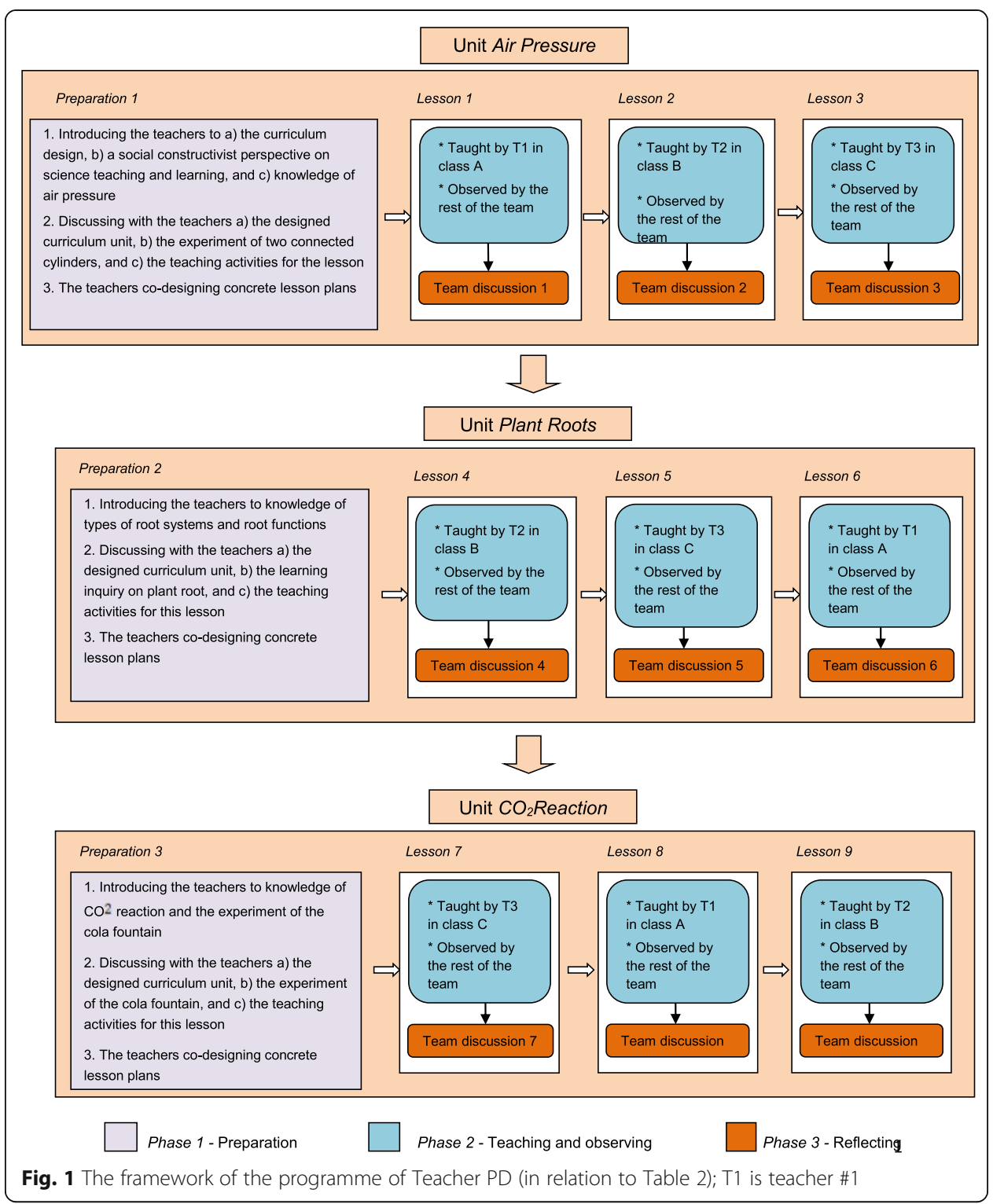

the-art knowledge on Teacher PD and design knowledge on curriculum frameworks and units. The framework presented in Fig. 1 can be considered a knowledge synthesis between PD and curriculum design (Bulte et al. 2006). In this programme of Teacher PD, knowledge of the establishment of learning communities with a facilitator (the first author) and the teachers as critical co-designers (Agung 2013) was also adapted and applied. Through the spiral approach the three teachers changed sequence in teaching the units, so that each teacher was able to teach a first lesson in a unit (Fig. 1). This balanced the pattern of hierarchy between participants, with the aim of stimulating the development of equitability and the prevention of hierarchy among the teachers. This is also consistent with a social constructivist approach which emphasises equitability (Beck and Kosnick 2006).

Three Vietnamese primary teachers, whose teaching approaches were analysed in an earlier study, were selected by the first author for the Teacher PD programme. These teachers were considered as $\mathrm{CHC}$ teachers because their observed teaching 
characteristics were aligned with a traditional $\mathrm{CHC}$ teacher ( $\mathrm{H}$ ng et al. 2015), as described in Table 1. These teachers were willing to experience new methods of teaching with the designed curriculum and stimulated by the board of the school. The information about these teachers (shortly described with T1, T2 and T3) is presented in Table 2.

All participating teachers come from a public primary school in Bacninh, a small urban area located in the North of Vietnam. This school can be considered representative of other primary schools in Vietnam. It is labelled as a National Standard School since it satisfies requirements on facilities and teaching quality. It has been applying a centralised science curriculum, which is prescribed by the Ministry of Education and Training. This science curriculum is used by most of the primary schools in the country. Bacninh is a province that has an agricultural economics developed for long years but now industrialisation has being taken place. The three units (Appendix 2) were taught by all the participating teachers. In total, nine lessons were prepared and codesigned, taught and observed, and, finally, discussed. The programme of Teacher PD took place within a period of six months with twelve face-to-face meetings (Fig. 1), and ten communications by emails.

\section{Data collection}

A qualitative methodology was applied in this study. Three main data sources were employed: classroom observations, students' feedback through questionnaires and interviews, and post-lesson discussions with the teachers. Each of the data sources is described in detail below.

\section{A. Classroom observations}

Classroom observations were considered to provide visible findings on the changes in the activities of the teachers and their approaches that occurred in classroom practice. Classroom observations were carried out by the first author and the teachers who did not teach the lesson. All of the observers were required to take field notes during the observations. The themes for classroom observations were established and provided for the teachers through the following questions:

1. What do you think about the lesson? Why?

2. What do you think about the teacher's practice in this lesson? Why?

3. What do you think about the students' learning in this lesson? Why?

Video and voice recordings were utilised for all of the observed lessons. A camera was located at a convenient place in each classroom to gain the best overview of the lesson. All of the video tapes were watched carefully and transcribed verbatim.

Table 2 Participating teachers

\begin{tabular}{llllll}
\hline Teacher & Age & Experience (in years) & Class (in charge) & Class size & Student age \\
\hline T1 & 38 & 18 & A & 31 & 10 \\
T2 & 36 & 16 & B & 24 & 10 \\
T3 & 30 & 8 & C & 27 & 10 \\
\hline
\end{tabular}




\section{B. Student questionnaires}

Questionnaires were employed to help the researchers reach a large population of the students who could provide their reflections on the experimental lessons. The questionnaires comprised the following questions:

1. To what extent do you like the lesson? Why?

2. Is the lesson different from or similar to your conventional science lessons? Please specify differences or similarities.

3. What do you think about the three lessons you were involved in? Compare them to your conventional science lessons.

4. What is the lesson you like most among the three lessons you were involved in? Why?

The first and second questions were administrated after every lesson, while the third and fourth questions were administrated only after the teaching of all of the lessons. The first and fourth questions used Likert scales with the scale: $1=$ not at all, $10=$ very much. This scale was designed similar to the Vietnamese grading system (a 1-10 point scale) that the students were familiar with. The second and third questions were openended.

\section{Student interviews}

The interviews took place to help the authors obtain elaborative feedback from the students. Thereby, changes in teachers could be recognised more explicitly. Semistructured interviews were organised after each lesson with the participations of 1-5 students, depending on their cooperation willingness and time availability. These students were selected randomly by the first author. In these interviews, the questions used in the questionnaire surveys were used and elaborated based on the initial answers of the students. The students were encouraged to provide specific examples for ideas regarding the changes they noticed in their teachers. The interviews with students took place face to face individually or in groups of three to five students. All of the interviews were voice recorded and transcribed verbatim.

\section{Post-lesson discussions with the teachers}

The post-lesson discussions with the teachers aimed to provide the teachers with opportunities to discover differences and similarities between the social constructivismbased science lessons and the science lessons they usually taught. The discussions helped the researchers to discover changes in the teachers' perceptions about science teaching and learning.

All of the teachers were involved in face-to-face discussions after every lesson when the themes of classroom observations were elaborated under the guidance of the first author. The researcher (the first author) in the post-lesson discussion played a main role as a chairwoman who asked questions to (i) lead the teachers for analysing and reflecting the enacted lessons and to (ii) elaborate the teachers' answers for achieving their knowledge on the designed curriculum and social constructivist teaching and learning of science. When the teachers orally shared their opinions, the researcher kept 
a role as an active listener who did not interrupt or correct the teachers. For some cases when the teachers did not have a consensus or clear ideas in enacting next lessons, the researcher could provide them with optional suggestions and remained an open-minded attitude with their decision to do. In this way, the researcher showed her roles as a researcher, a co-designer and a neutral and constructivist person in the postdiscussion. The teachers were encouraged to feel free to share personal opinions and evaluate the designed curriculum and the experimental lessons. Based on their answers for the overall questions (the themes of the classroom observations), the teachers were gradually encouraged to zoom in on, analyse, and evaluate teaching and learning discourses in detail. Two key issues in the analysis and evaluation of the lessons and teaching discussed with the teachers are expressed in the following questions:

1. Are the students socially interactive in learning in the lesson? To what extent are they interactive during each of the phases? If to a small extent, what should be changed in the lesson design? And what should the teacher do in the next lessons to improve students' social interactions?

2. Do the students construct knowledge by themselves? To what extent do they construct knowledge? If to a small extent, what should be changed in the design of the lesson? And what should the teacher do in the next lessons to improve students' construction of knowledge?

All of the discussions with the teachers were audiotaped and transcribed verbatim.

Both students' feedback (from the questionnaires and interviews) and the knowledge the teachers agreed upon in the post-lesson discussions were summarised in single reports by the first author and regularly sent to the teachers before the next lesson. In total, nine reports were made and structured based on the following elements:

a. General evaluations about the recent lesson, which were categorised in two groups: achievements and shortcomings or problems. Students' reflections on the lesson were embedded in a summary or in quotations.

b. Consensually agreed suggestions for the design and teaching activities to apply in the next lessons.

c. Additional literature on social constructivist teaching and learning

The brief summaries (elements $a$ and $b$ ) of these nine reports are presented in Table 3.

In addition, the teachers were encouraged to explore more of the content knowledge regarding air pressure, plant roots, and $\mathrm{CO}_{2}$ reactions by contacting other science teachers and using the internet.

\section{Data analysis}

To answer the first research sub-question - What changes are there in the attitudes and activities of the teachers in classroom practices through their interaction with the designed curriculum appropriate for a CHC? - the characteristics of a social constructivist teacher and a traditional CHC teacher presented in Table 1 were used as organising elements to characterise the teachers' changes in practices. The characteristics of 
Table 3 Reports on the experimental lessons (in relation to Figure 1)

\begin{tabular}{|c|c|c|}
\hline Report & Achievements & Shortcomings/Problems \\
\hline Lesson 1 & $\begin{array}{l}\text { Students were active and excited in doing } \\
\text { hands-on activities }\end{array}$ & $\begin{array}{l}\text { Students were passive in oral communications } \\
\text { with the teacher, who transmitted knowledge } \\
\text { rather than helping the students construct } \\
\text { knowledge }\end{array}$ \\
\hline Lesson 2 & Students were active in cooperative tasks & $\begin{array}{l}\text { Knowledge was sometimes imposed on students } \\
\text { by the teacher }\end{array}$ \\
\hline Lesson 3 & $\begin{array}{l}\text { The teacher was effective in developing } \\
\text { elaborative questions }\end{array}$ & $\begin{array}{l}\text { The one-way interaction from teacher to students } \\
\text { was rather dominant }\end{array}$ \\
\hline Lesson 4 & $\begin{array}{l}\text { The lesson was developed as designed and } \\
\text { the students enjoyed the lesson }\end{array}$ & $\begin{array}{l}\text { The students were still passive and static in } \\
\text { learning in the Exchange phase }\end{array}$ \\
\hline Lesson 5 & $\begin{array}{l}\text { The students were enthusiastic in learning, } \\
\text { especially in the Experience phase }\end{array}$ & $\begin{array}{l}\text { The teaching and learning in the Exchange } \\
\text { phase did not lead to the active participation } \\
\text { of the students }\end{array}$ \\
\hline Lesson 6 & $\begin{array}{l}\text { The interaction between students became } \\
\text { dominant in the lesson and the students were } \\
\text { highly enthusiastic in learning }\end{array}$ & $\begin{array}{l}\text { The teacher was rather confused in dealing with } \\
\text { some of the students' answers }\end{array}$ \\
\hline Lesson 7 & $\begin{array}{l}\text { The teacher was notably effective in creating } \\
\text { elaborative questions to help the students } \\
\text { construct knowledge }\end{array}$ & $\begin{array}{l}\text { Scientific argumentation in students' discussions } \\
\text { was still limited }\end{array}$ \\
\hline Lesson 8 & $\begin{array}{l}\text { The students were engaged in the experiment } \\
\text { and excited about learning }\end{array}$ & $\begin{array}{l}\text { Scientific argumentation in students' discussions } \\
\text { was still limited }\end{array}$ \\
\hline Lesson 9 & $\begin{array}{l}\text { Teaching activities were arranged to correspond } \\
\text { smoothly to each of the phases }\end{array}$ & $\begin{array}{l}\text { The students were not provided with enough } \\
\text { guidance to be effective in answering some of } \\
\text { the teacher's questions when the students had } \\
\text { to apply their knowledge to a new problem }\end{array}$ \\
\hline
\end{tabular}

the teachers in teaching the experimental lessons were compared to those of a social constructivist teacher and to those of a traditional $\mathrm{CHC}$ teacher (Table 1). This characterisation was primarily determined by classroom observations (Source A) and was triangulated with data from the student questionnaires (Source B) and the student interviews (Source C). The characterisation of changes in teachers' attitudes and activities in the experimental lessons was first created by the first author. Then it was sent to the participating teachers to verify and come to an agreement among the members of the team. After that, the characterisation was discussed thoroughly with the second author several times. It was later discussed and validated again in the entire research group before reaching a final consensus. The discussions provided opportunities to cross-check and validate data (Creswell 2009).

To answer the second research sub-question - How do the teachers perceive the designed curriculum appropriate for a CHC? and the third research sub-question - What do the teachers perceive as major challenges to the implementation of the designed curriculum appropriate for a CHC?, the data source of discussion with the teachers (Source D) was employed and analysed. All of the discussion with the teachers was transcribed and provided with raw data in texts, which was organised and prepared for analysis. The texts were carefully read by the first author to achieve a general sense of the information and an opportunity to reflect on its overall meaning. After that, the texts were coded (by the first author) by bracketing chunks and writing words representing categories and themes in the margin. For the ways that the teachers perceived the designed curriculum, the data was coded and aggregated into three themes, they were: a) Students' benefits, b) Reconceptualising science teaching and learning, and c) Formulation of teacher activities (for Research sub-question 2). For the challenges of 
curriculum implementation perceived by the teachers, the two categories were applied and labelled as 1) Teacher challenges and 2) Institutional challenges (for Research subquestion 3). With each of these categories, the coding was used again to generate a small number of themes. With respect to the category of teacher challenges, the themes were: a) the influences of habits and traditional teaching and learning methods, b) the need for deep understanding of scientific content knowledge, and c) the difficulty of teaching and learning argumentations. With respect to the category of institutional challenges, the themes were: a) the issue of time, b) the assessment of learning results, and c) the difficulty associated with systemic changes. All of the themes were afterwards used as the headings in the findings sections and shaped into general description by narrative passages with quotes, which were used as evidences to convey the findings of the analysis. The meanings of the themes and descriptions were interpreted for the learned lessons and suggestions from the study.

The findings validation was implemented in two main strategies with hierarchical steps to ensure the accuracy of the findings. Firstly, member checking was implemented through taking the specific descriptions back to the participant teachers to ensure that all the major findings, the themes, the case analysis, were accurate. With the confirmation from the participants teachers to the product, detailed descriptions were made by the first author and then intensively discussed for several times with the second author and later in the whole author team in order to come to a complete consensus on the findings. In this way, a rich and thick description and accurate findings on the perception of $\mathrm{CHC}$ primary teachers regarding the designed curriculum and the challenges to apply it in practice were produced (Cresswell 2009).

\section{Findings}

The programme of Teacher PD with three main stages - preparation for teaching, teaching and observing, and reflection, with quite a number of small iterations in which general strategies such as collaboration, sharing experiences, co-designing were applied - showed its effectiveness in helping Vietnamese teachers in a $\mathrm{CHC}$ have changes in attitudes, activities, and knowledge of science teaching towards a social constructivist approach. The findings are presented below according to the three aforementioned subquestions.

\section{Changes in Vietnamese teachers' attitudes and activities}

Changes in attitudes and activities were gradually implemented by the Vietnamese teachers in the experimental lessons. These changes did not always consistently move toward social constructivist teaching over the course of the experimental lessons. Sometimes, the changes did not occur in the later experimental lessons although they had already occurred in the previous lessons. Overall, however, changes in teachers' attitudes and activities towards social constructivist teaching did take place. The changes in attitudes and activities of Vietnamese teachers during their interaction with the designed curriculum are summarised and presented in Table 4 and are described below in detail.

As seen in Table 4, a few aspects of a social constructivist approach came to the fore in the first three lessons. The changes were moderate in Lessons 4 and 5, which could be considered as the middle lessons in the transition from traditional teaching to social 


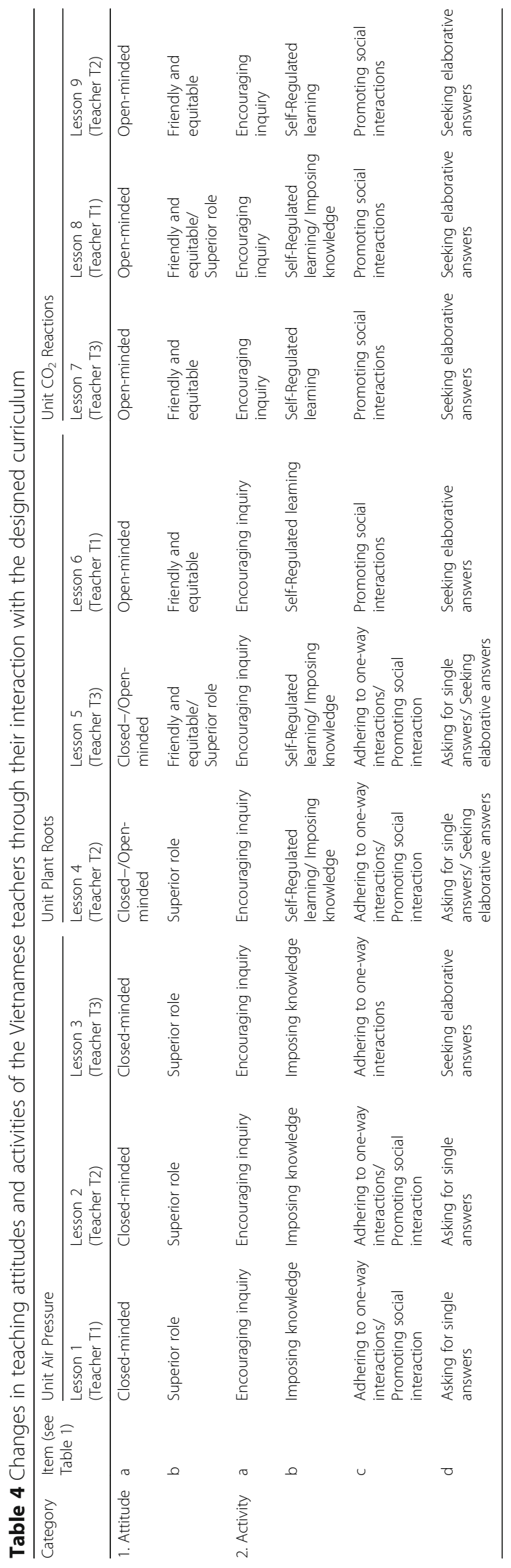


constructivist teaching. The teachers' changes became significant in the last four lessons. The changes in teachers' attitudes and activities are described below in more detail.

\section{1a. Being open-minded}

In the first three experimental lessons, all of the three teachers often judged students' answers based on a "correct or incorrect" standard (Source A). Specifically, the words such as right, correct, incorrect, or false were used many times by all three teachers T1, T2, and T3 to assess students' answers in these lessons (Source A). These direct-assessing words were considerably used less by teachers T2 and T3 in lessons 4 and 5 (Source A). In both of these lessons, the students were organized to learn outdoor in small cooperative groups to interact with real plants for the phase of Experience. For the cases of teacher - students interactions that were observed directly at site or heard by the researcher when she carefully watched video records again, the word "correct" was mentioned by teacher T2 for 7 times and by teacher T3 for 5 times. The direct-assessing words were not used at all by any of the teachers in the last four lessons (Source A). Rather, in these lessons, more neutral assessing words and expressions, i.e. properly, interesting, and it sounds plausible, were used by all of the teachers to assess the answers of the students (Source A).

The findings from the class observations were consistent with those from the student interviews. All of the interviewed students acknowledged the teachers' openmindedness in the last four lessons and contended this was one of the significant changes of Teachers T1, T2, and T3 (Source C). For instance, the interviewed students acknowledged that teacher T1 had become more tender, humorous and easy-going in Lesson 6. According to them, they were encouraged by Teacher T1 to speak their thoughts freely in order to answer questions. Hence, many "funny-sounding" words and expressions were pronounced by the students, i.e. the root system of grass being compared to thinly shredded meat (Source C). The students expressed that such a "funny-sounding" expression would not have been accepted by Teacher T1 as in their conventional science lessons; therefore, the students would have avoided using it in their conventional lessons. Similar ideas of the students showing the open-mindedness characteristic that Teachers T1, T2, and T3 performed in the last four lessons were also recognised in the other interviews with the students (Source $\mathrm{C}$ ).

The open-mindedness of Teachers T1, T2, and T3, was emerged in the students' answers to the questionnaires for the last four experimental lessons and confirmed this finding (Source B).The quotation below can illustrates this:

I like the lesson today because I was more self-confident and volunteered to pose ideas.... I see that my peers posed ideas and discussed more than in our usual science lessons. (Student Quynh about Lesson 7; Source B).

The above quotation shows that the students were more engaged and more active in the experimental lesson than in their conventional lessons. This learning characteristic could have been supported by the teachers' open-mindedness that could well have provided students with more confidence and opportunities to assume ownership in their learning. 


\section{1b. Being friendly and equitable}

In the first four experimental lessons, the teachers $\mathrm{T} 1, \mathrm{~T} 2$, and $\mathrm{T} 3$ maintained a superior role in their communication with the students (Source A). Though the students were highly active and enthusiastic in the Engagement and Experience phases (see Appendix 1 and 2), they were passive and static in the Exchange phase (Source A). The superior role remained moderate in Lessons 5 and 8 by Teacher T3 and T1 (Source A). The teachers T1, T3, and T2 showed an explicitly friendly and equitable attitude in Lessons 6, 7, and 9, correspondingly (Source A). This finding was consistent with what was reflected by the students through their answers in the questionnaires and in the interviews (Sources B and C). The following quotations illustrate this:

The teacher was gentler than in the usual lessons. She did not reprimand us at all when we provided wrong answers. (Student Cuong about Teacher T1, Lesson 6; Source C).

Today the teacher spoke and questioned softly and in a friendly manner. (Student Linh about Teacher T3, Lesson 7; Source B).

The students' characterisation of their teachers' discourses as gentle, not reprimanding students for wrong answers, and speaking and questioning softly in their communications with the students represented the friendly and equitable attitude that the teachers demonstrated in the later experimental lessons.

\section{2a. Encouraging students to engage in inquiry}

In all nine of the lessons, inquiry activities were encouraged by all of Teachers T1, T2, and T3 (Source A). The students were provided with hands-on cooperative tasks and the teachers often asked the students to reason and explain their ideas (Source A). In their reflection on the experimental lessons, all of the students acknowledged that Teachers T1, T2, and T3 provided opportunities for them to engage in and carry out experiments and group discussions and this made them active and enthusiastic in learning (Sources B and C). They stressed that these activities were absent in their conventional science lessons and the hands-on activities made the experimental lessons in their perception completely different compared to the conventional science lessons (Sources B and C). The teachers' encouragement of inquiry on the part of students can be found in the following quotations:

The lesson was wonderful because it made me feel like a scientist. (Student Chien about Lesson 6, Teacher T1; Source B).

Great! We did experiments. We discussed with each other; spoke out what we thought. (Student Thong after three lessons; Source B).

The students' quoted expressions, such as feel like a scientist, we did experiments, and discussed with each other show that inquiry activities were organised and encouraging for students.

\section{2b. Providing time and space for self-regulated learning}

In the first three experimental lessons, Teachers T1, T2, and T3 did not provide time and space for self-regulated learning in the inquiry tasks of the Experience phase 
(Source A). In these lessons, Teachers T1, T2, and T3 reached student groups and provided them with guidance and questions right after they delivered the cooperative inquiry tasks (Source A). In Lessons 4, 5, and 8, the teachers (T2, T3, and T1) provided a bit more time and space for self-regulated learning in the Experience phase (Source A). This had changed considerably in Lessons 6, 7, and 9 wherein Teachers T1, T3, and T2 took the roles as a learning observer and a supervisor while the students were accomplishing the cooperative inquiry tasks (Source A). The various positive reflections of the students about Lessons 6, 7 and 9, obviously manifested that the teachers (T1, T3, and T2) had provided them with time and space to discuss and explore scientific subject matter (Sources B and C).

I find this lesson freer than the usual science lessons. (Student Ha about Lesson 6, Teacher T1; Source C).

I found the teacher was more patient with us [...]. (Student Ly about Lesson 7, Teacher T3; Source B).

The words freer and patient mentioned by the students to characterise their feelings about the specific lesson (Lesson 6) and teacher (Teacher T3) may indicate the autonomy and ownership that the students had been provided in the experimental lessons.

\section{2c. Promoting social interactions among students}

Generally, social interactions among the students were not very frequently promoted by Teachers T1, T2, and T3 in the first five experimental lessons, especially in Lesson 3 (Teacher T3), in which one-way interaction from teacher to students was dominant (Source A). Social interactions among students were promoted by all Teachers T1, T2, and T3, in the last four experimental lessons, especially in Lesson 6 (Teacher T1), in which the students were highly active in discussions (Source A). The students in Lessons 6, 7, 8, and 9, acknowledged and highlighted the cooperative learning environment that Teachers T1, T2, and T3 had organised for them in these lessons (Sources B and C).

The lesson was very interesting. My peers were very noisy and enthusiastic. They provided many ideas. (Student Lan about Lesson 6, Teacher T1; Source B).

I see Duc Anh [one of the students] changed a lot in the lesson today. He rarely posed his ideas in the usual lessons. Normally, he sat quietly and listened to the teacher and his peers. However, today he was very enthusiastic in posing his ideas and had many initiatives for our group. (Student Chi about Lesson 9, Teacher T2; Source C).

The learning characteristics mentioned in the above quotations, along with the specific example of a student (Duc Anh) who had changed toward a more interactive way of learning, show that social interactions were promoted by the teachers (T1, T2, and T3) in those experimental lessons.

\section{2d. Seeking elaboration of students' initial responses}

In the first two lessons, Teachers $\mathrm{T} 1$ and $\mathrm{T} 2$ provided the students with single questions rather than elaborative questions developed from students' initial responses (Source A). This can be illustrated by a conversation between Teacher T2 with her students in Lesson 2, as presented below: 


\begin{tabular}{|c|c|c|}
\hline 1 & Teacher T2 & $\begin{array}{l}\text { Please present for me your result of exercise } 2 \text { ! The others listen } \\
\text { to the peer and see whether your group has the same ideas or } \\
\text { not. If yours are different, you will give supplementary ideas then, } \\
\text { ok? Group 3, please! }\end{array}$ \\
\hline 2 & Student Hoa & $\begin{array}{l}\text { There is air in the cylinders so when we pressed one cylinder down, the } \\
\text { other came out. }\end{array}$ \\
\hline 3 & Teacher T2 & $\begin{array}{l}\text { Ok. That is the idea of Hoa's group. They said that when one } \\
\text { cylinder was pressed down, the other would come out. And they } \\
\text { explained that it is because the air transferred through the plastic } \\
\text { tube pushed the other out to make room for the air to come in. } \\
\text { What about the ideas of Group 1? }\end{array}$ \\
\hline 4 & Student Hung & (Spoke so softly that it was difficult to hear) \\
\hline 5 & Teacher T2 & What happened with the other cylinder? Please speak loudly! \\
\hline 6 & Student Hung & It was jut out. \\
\hline 7 & Teacher T2 & Ah, it was jut out. What is your explanation? \\
\hline 8 & Student Hung & $\begin{array}{l}\text { The air is transferred through the cylinders and pressed the other } \\
\text { cylinder down. }\end{array}$ \\
\hline 9 & Teacher T2 & Ok. Group of Hieu, please! \\
\hline 10 & Student Minh & (Spoke so softly that it was difficult to hear) \\
\hline 11 & Teacher T2 & $\begin{array}{l}\text { Ok. Group 4, please present your discussion results. Do you agree with } \\
\text { the groups' ideas? }\end{array}$ \\
\hline 12 & Student Lieu & I agree with the idea of Group 3. \\
\hline 13 & Teacher T2 & Do you have anything to add in? \\
\hline 14 & Student Lieu & $\begin{array}{l}\text { When one cylinder is pressed down, the other cylinder will jut out } \\
\text { because the air is transferred through the cylinders and pushes the } \\
\text { other cylinder out. }\end{array}$ \\
\hline 15 & Teacher T2 & $\begin{array}{l}\text { Ok. Your ideas are almost similar with each other. So, do you have } \\
\text { any question related to this experiment that you want to discuss } \\
\text { with peers? Group 2, please! }\end{array}$ \\
\hline 16 & Student Hieu & Why can't we press the two cylinders down at the same time? \\
\hline 17 & Teacher T2 & Who can explain for Hieu? \\
\hline 18 & Student Dung & $\begin{array}{l}\text { Because the air in the plastic tube is full, it can't be pressed down } \\
\text { anymore. }\end{array}$ \\
\hline 19 & Teacher T2 & What about the other groups' ideas? Van, please! \\
\hline 20 & Student Van & $\begin{array}{l}\text { The air in the two cylinders touches each other so it can't be pressed } \\
\text { down. }\end{array}$ \\
\hline 21 & Teacher T2 & What about the others? What are your ideas? \\
\hline 22 & Student Thanh & $\begin{array}{l}\text { When pressing the two cylinders down at the same time, the air in } \\
\text { these cylinders meets each other so it can't be pressed down. }\end{array}$ \\
\hline 23 & Teacher T2 & Do you have any question to discuss with peers? \\
\hline
\end{tabular}

As showed in the conversation above, the teacher asked the students many questions, however, her questions are not coherent or connected much with each other. This way could not help the students effectively construct knowledge about air pressure. However, Teachers T2 and T3 were able to use elaborative questions developed from students' initial responses much more in Lessons 4 and 5 (Source A). Teacher T3 did well in seeking for elaborative answers from the students in Lesson 3. This teacher activity was done by all of Teachers T1, T2, and T3 as in the last four experimental lessons (Source A). For instance for Teacher T3 in Lesson 3: 


\begin{tabular}{|c|c|c|}
\hline 1 & Teacher T3 & What did you observe? \\
\hline 2 & Student Ly & $\begin{array}{l}\text { When the first cylinder was pressed down, the air pushed the connected } \\
\text { second cylinder up. }\end{array}$ \\
\hline 3 & Teacher T3 & Why did that happen? \\
\hline 4 & Student Ly & $\begin{array}{l}\text { Because the first cylinder pressed the air down and made the second one } \\
\text { jut out. }\end{array}$ \\
\hline 5 & Teacher T3 & What do you mean by "the air"? \\
\hline 6 & Student Manh & The air in the cylinders. \\
\hline 7 & Teacher T3 & How did the air do that? \\
\hline 8 & Student Manh & It was pressed down and made the cylinder go out. \\
\hline 9 & Teacher T3 & Who can explain it more explicitly? \\
\hline 10 & Students & (No answer) \\
\hline 11 & Teacher T3 & $\begin{array}{l}\text { Let's observe! (Doing the experiment). When I pressed the first cylinder down, } \\
\text { do you think the amount of air in the cylinders changed? }\end{array}$ \\
\hline 12 & Student Cuong & No, it didn't change. \\
\hline 13 & Teacher T3 & It didn't change, did it? So how does it work? \\
\hline 14 & Student Cuong & It was kept in. \\
\hline 15 & Student Ly & It was hardened. \\
\hline 16 & Student Thao & It was compressed down. \\
\hline 17 & Teacher T3 & Good! The air was compressed down and what else? \\
\hline 18 & Student Thao & It created air pressure that made the other cylinder go up. \\
\hline 19 & Teacher T3 & So... what does it mean? What do you learn from this? \\
\hline 20 & Student Vy & Air can be compressed down or ... expanded. \\
\hline 21 & Student Hung & Air can create pressure. \\
\hline
\end{tabular}

As recognised in the above conversation between Teacher T3 and her students in Lesson 3 (Source A), the teacher's questions were often developed from the students' initial answers. This indicates that the teacher sought elaboration of the students' answers and gradually developed the thinking of the students in the lesson about air pressure.

This finding aligned with the one from analysing the students' reflections (Sources B and $\mathrm{C}$ ), as in the quotation below:

Normally the teacher teaches very quickly but today she taught very thoroughly. (Student Thai about Lesson 8, Teacher T3; Source C).

In summary, the teachers remained the basic characteristics of a traditional $\mathrm{CHC}$ teacher in the first two experiment lessons and moderately changed towards a social constructivist approach of teaching in Lesson 3, 4, and 5. The basic characteristics of a social constructivist teacher were explicitly manifested by them in the last four experimental lessons.

\section{Perceptions of Vietnamese teachers regarding the designed curriculum}

The teachers' perceptions of the designed curriculum are clustered in the three emerging themes: 1) the designed curriculum brings more benefits for students than the conventional science curriculum does; 2) the designed curriculum helps reconceptualise the teaching and learning of science; and 3) the designed curriculum needs to have a formulation of teacher activities corresponding with each of the phases. 


\section{Students' benefits}

The teachers acknowledged after the Teacher PD differences between the designed curriculum and the conventional science curriculum. According to them, the designed curriculum could bring more benefits for primary students, as detailed in the following quotations:

I see differences in teaching and learning between the two curricula. Within the current teaching methods applied in our conventional curriculum, what the teacher says can be "Silent!", "Quiet!", “Don't speak freely!" But with teaching and learning according to this curriculum, students are very free to pose ideas. (T1, Team discussion 6, Source D).

According to conventional lessons, students have to remember a body of knowledge; the difference with these lessons is that students have the opportunity to remember knowledge and can remember it for a longer time. (T1, Team discussion 9, Source D).

I found that this teaching and learning approach is good, gets students engaged in learning. (T3, Team discussion 9, Source D).

The teachers affirmed that the students in the experimental lessons were more active than in their conventional science lessons. They acknowledged that the students were more curious, excited, and active in learning.

\section{Reconceptualising science teaching and learning}

According to the teachers, the involvement in co-designing and teaching the experimental lessons of the designed curriculum made them change their perceptions of teaching and learning science. The teachers acknowledged that the teaching and learning methods of the conventional science curriculum emphasised transmissive teaching and reproductive learning. By analysing the differences between the experimental lessons and the conventional science lessons, the teachers showed their preference for social constructivist teaching methods for science lessons. This can be recognised in the quotations below:

Good science learning involves the consideration that knowledge is not always precise and correct, and hence, we should not impose "correct knowledge" on students. Students have to explore and discover, and they assess knowledge by themselves. (T1, Team discussion 6, Source D).

In this lesson, if a student does not know, thanks to her peers, she can know, right? If she knows already, thanks to her peers, she can know more. Hence, her knowledge becomes certain. Through exploring activities, she knows more again, so that she becomes more self-confident, courageous, and knowledgeable. However, in our conventional science lessons, the students depend on the teacher and they do not dare to ask the teacher to tell them more as they do when they work with their peers. (T3, Team discussion 9, Source D).

\section{The formulation of teacher activities corresponding with each of the phases}

Despite acknowledging advantages of the designed curriculum, the teachers pointed out its shortcomings and limitations. According to them, the designed curriculum did not provide enough instructive information or an instructional guideline specific enough for teachers to know with certainty what they should do when teaching the lessons. The designed curriculum was structured with two main learning tasks for the Experience phase (Appendix 1). However, the lack of a clear description of the teacher activities in relation 
to the designed student activities confused the teachers. The following quotation of Teacher T3 about the design illustrates this:

The most difficult thing is how to teach to help students understand the scientific matter. When I designed the lesson plan, I found it very difficult. So I had to come to ask one of my colleagues who is a Physics teacher. She provided me with her advices for teaching in phase Engagement and Experience [...]. Then I had ideas for my teaching activities. At the beginning, indeed I did not know what to do. (T3, Team discussion 7, Source D).

Two alternatives for teacher activities in phase Experience could be formulated by the teachers. They were generated and presented as below:

\section{Alternative 1}

Step 1. The teacher lets student groups complete both the predicting task and the experimental task (Appendix 1) in the Experience phase.

Step 2. The teacher lets students present all of the group answers for both the predicting task and experimental task and postpones the discussion of the outcomes until the Exchange phase.

\section{Alternative 2}

Step 1. The teacher lets student groups complete the predicting task in the Experience phase.

Step 2. The teacher lets students present predicting answers and lets them compare predicting answers with each other in the Experience phase.

Step 3. The teacher lets student groups do the experiment task in the Experience phase.

Step 4. The teacher lets student groups present their answers of the experiment, compare the experiment answers, and discuss these in the Exchange phase.

Step 5. The teacher lets student groups compare the predicting answers to the experiment answers and discuss these in the Exchange phase.

The teachers chose Alternative 1 to do in the first six lessons; from Lesson 7 onwards, they decided to apply Alternative 2. According to the teachers, Alternative 1 confused students and they found it difficult to catch key ideas of other groups in order to assess answers because many of the answers were presented at the same time. This made the students feel bored and less motivated to share ideas. The teachers considered Alternative 1 (applied in the first six experimental lessons) as one of the explanations for a less active learning atmosphere in the Exchange phase than in the other phases. The Exchange phase could in Alternative 1 easily return to traditional teaching and learning. (Source D).

The teachers preferred Alternative 2 because students had opportunities to find similarities and differences in group answers within and between the tasks. The teachers acknowledged that the comparisons meant that the teaching and learning was better structured and student groups were more motivated for the next learning step. The teachers evaluated that in Alternative 2 they could follow the students' learning step by step; hence, they could do their teaching in a better way and were able to assess the students' learning adequately (Source D). 
In reflecting on the designed curriculum and their experimental lessons, the teachers stressed the need for adding explicit teacher activities in order to help $\mathrm{CHC}$ teachers avoid practical difficulties when implementing the designed curriculum (Source D). The following quotation can reflect such an opinion of the teachers:

How the teacher leads and prompts students to help them find knowledge is indeed a process. How to talk, how to do, how to guide, and how to connect things, are most important, aren't they? (T1, Team discussion 7, Source D).

Based on their own experiences of co-designing, teaching, and reflecting on the experimental lessons in the spiral PD programme, the teachers formulated a set of teacher activities to be applied to the design, thereby showing their understanding of the design after the Teacher PD programme.

The teacher should keep the roles as an organiser and a stimulator to students, a diagnostician for learning problems that need to be solved timely and adequately. The students should keep the roles as investigators and explorers. They should be active in interactions of student - student and student - teacher. (T2, Team discussion 9, Source D).

I think the teaching according to your curriculum should be like this: First, in phase Engagement, the students need leading to a scientific matter that raises in them a desire to explore. Second, the students do prediction and explanation related to an experiment. They need to do observations. For these activities, the students are to be organised to work in small groups to cooperate and discuss based on the task of Exercise 2. The role of teacher is most important then. She needs to go around the groups, observe them to know how they discuss; if necessary, she will give them leading questions and prompts so that they can understand the matter. The students do presentations in class as a whole or in mixed groups. If there are conflicts or rebuttals in the students' discussion, the roles of the teacher are needed again [...]. The teacher needs to give open-ended questions to guide the students, let them talk and share more ideas. (T3, Team discussion 7 , Source D).

These teacher activities were formulated corresponding to each of the learning phases and helped the curriculum design to become more complete and easier for $\mathrm{CHC}$ teachers to use. The teacher activities were formulated to add into the designed curriculum and are presented in Table 5.

\section{Challenges for the application of the designed curriculum}

In the discussion, the teachers showed their perceptions on the challenges for applying the designed curriculum into practice of primary education in a $\mathrm{CHC}$. The challenges were aggregated in two categories: 1) teacher challenges and 2) institutional challenges. The teacher challenges were described by three themes, they were a) the influences of habits and traditional methods, b) the need for understanding scientific subject matter, and c) the difficulty of teaching and learning argumentation. The institutional challenges were described by two themes, they were a) the issue of time for teaching, b) the assessment of learning results, and c) the difficulty associated with systemic change. 
Table 5 The teaching activities proposed by the $\mathrm{CHC}$ teachers to apply to the designed curriculum

\begin{tabular}{|c|c|c|c|}
\hline \multirow[t]{2}{*}{ Phase } & \multicolumn{3}{|c|}{ Teaching activity } \\
\hline & Number & Repeated & Items \\
\hline \multirow[t]{2}{*}{ Engagement } & $\mathrm{i}$ & & Using a few key questions to reveal students' prior knowledge and curiosity \\
\hline & ii & & Staying open to students' responses \\
\hline \multirow[t]{12}{*}{ Experience } & & & PREDICTING \\
\hline & iii & & $\begin{array}{l}\text { Delivering the task and being sure that student groups know what to do } \\
\text { and how to do the task }\end{array}$ \\
\hline & iv & & Establishing time for group discussion \\
\hline & $v$ & & Observing and supervising groups while they do their group tasks \\
\hline & vi & & Encouraging students to present answers, and compare and assess answers \\
\hline & vii & i & Staying open to students' responses \\
\hline & & & HANDS-ON \\
\hline & viii & iii & $\begin{array}{l}\text { Delivering the task and being sure that student groups know what to do } \\
\text { and how to do the task }\end{array}$ \\
\hline & ix & iv & Establishing time for group discussion \\
\hline & $x$ & $v$ & Observing and supervising groups while they do their group tasks \\
\hline & xi & & Using open-ended elaborative questions to guide students \\
\hline & xii & & Staying open-minded and friendly while interacting with students \\
\hline \multirow[t]{5}{*}{ Exchange } & xiii & vi & Encouraging students to present answers, and compare and assess answers \\
\hline & xiv & & Stimulating groups to interact and argue with each other \\
\hline & $x v$ & xi & $\begin{array}{l}\text { Using open-ended elaborative questions to guide students in grasping } \\
\text { deeper knowledge }\end{array}$ \\
\hline & $x v i$ & xii & Staying open-minded and friendly while interacting with students \\
\hline & xvii & & $\begin{array}{l}\text { Choosing representative questions formulated by students/groups for } \\
\text { students to discuss and answer }\end{array}$ \\
\hline \multirow[t]{2}{*}{ Follow-up } & xviii & xi & $\begin{array}{l}\text { Providing open-ended sub-questions (if necessary) to guide students in } \\
\text { answering/solving new questions/problems }\end{array}$ \\
\hline & xix & & $\begin{array}{l}\text { Giving compliments to individual students and groups who have achieved } \\
\text { successful learning }\end{array}$ \\
\hline
\end{tabular}

\section{Teacher challenges}

\section{A. The influences of habits and traditional teaching methods}

According to the teachers, when teaching the experimental lessons they were influenced by their existing habits and the traditional teaching and learning methods of the conventional science curriculum, especially in the first three experimental lessons. This was expressed in the following statements:

To apply this curriculum, teachers are required to change their minds. In our usual lessons, the teacher is already provided with solid knowledge written in the textbooks; what she needs to do is to convey it to students. But for the lessons of this innovative curriculum, the teacher needs to self-prepare knowledge.... In the first situation, the knowledge source is available to the teacher and the teacher just fills the vase with it. The second situation requires the teacher to have and select a suitable knowledge source and also to know how to use it for teaching. This is difficult. (T1, Team discussion 6, Source D).

Sometimes we might have used traditional methods unintentionally when teaching these lessons. This is because we have been deeply influenced by a traditional teaching method and used it for quite a long time. (T1, Team discussion 9). 
The teachers used these arguments to explain why they applied a transmissive teaching style and judged students based on a "correct or incorrect" standard in the first experimental lessons, although they were aware that they should not have done so. They acknowledged that habits of traditional teaching methods were considerable challenges for Confucian heritage teachers aiming to teach the designed science lessons.

\section{B. The need for deep understanding of scientific content knowledge}

The teachers acknowledged that one of the difficulties they had to cope with was that they did not have enough content knowledge about air pressure, plant roots, and $\mathrm{CO}_{2}$ reaction to teach these scientific themes to their students, although they were provided with literature in the PD programme. To teach these lessons, they had to look for information and knowledge on these scientific themes by searching the internet and consulting their science colleagues. They showed a need for deep understanding of scientific content knowledge when implementing the designed curriculum, as is illustrated in the following quotation:

If the teacher does not have enough knowledge and information on scientific content, she cannot guide students to solve problems. (T3, Team discussion 9, Source D).

According to the teachers, it was difficult for them to formulate effective open-ended questions to guide students to grasp knowledge when they themselves did not understand the subject matter well enough. Therefore, they stressed that the teachers' understanding of content knowledge played a crucial role when teaching the lessons.

With the [new] approach [...], the teacher needs to know more about content knowledge, and she needs to search for knowledge to stay independent in her own thinking. (T3, Team discussion 6, Source D).

However, according to the teachers, Vietnamese primary teachers teach many subjects, of which the main ones are mathematics and Vietnamese, and they are overloaded with work. Pre- and in-service teacher education did not provide much content knowledge about science, which explains why primary teachers have insufficient content knowledge about science. It was therefore challenging to search for deeper content knowledge.

In the teachers' opinions, the designed curriculum requires teachers to have a higher capability in pedagogy to guide students and cope with problems and questions because the curriculum encourages students to pose questions and to raise conflicts in discussions and argumentation. To guide students in answering questions, resolving conflicts in discussions, and arguing with each other requires that teachers are well equipped with scientific content knowledge.

\section{The difficulty of teaching and learning argumentations}

Scientific argumentation was found to be challenging. According to the teachers, social conflicts in argumentation occurred during the experimental lessons. Then the students tended to wait for the teacher's interventions or let the group leader decide on the final answers rather than arguing with each other. The teachers found it difficult to help the students resolve such conflicts, because they did not have sufficient skill in scientific argumentation. In such a situation, the learning environment could easily return to passive learning as in traditional classrooms.

It's difficult for teachers to teach students how to reason, argue, and defend their ideas. (T2, Team discussion 8, Source D). 
We feel that it is difficult to teach the Exchange phase. It is not easy to promote argumentation among students in this phase. That's why I think in this phase the students' learning was less active than in the other phases. (T1, Team discussion 9, Source D).

It is understood from the teachers that teaching and learning argumentation in primary education in Vietnam is more challenging than in Western countries because the Vietnamese culture supports hierarchy, academic knowledge, and stability. According to them, Vietnamese primary students adhere the thought that teachers are always right and teachers adhere the thought that texts in textbooks are always correct. In Vietnam, teachers were traditionally acknowledged to have academic knowledge higher than students', advanced students' to have academic knowledge higher than their peers', and textbook writers' to have academic knowledge higher than the teachers'. The hierarchy was manifested by the fact that people at higher academic knowledge levels were often treated as at higher positions. The teachers believed that scientific argumentation involves thinking skills, however Vietnamese culture values more on academic knowledge, the main objective of school curricular is about developing knowledge for students.

Our education does not teach students thinking skills but just knowledge. (T3, Team discussion 8, Source D).

I find lessons in the conventional curriculum easier to teach than those in the designed curriculum. In the conventional curriculum, what the teacher needs to do is just transmitting knowledge to students. (T1, Team discussion 9, Source D).

The teachers considered scientific argumentation as one of the emergent elements of the social constructivism-based curriculum that makes it different with their conventional science curriculum.

There are resistances to changes and new things in our culture. (T3, Team discussion 9, Source D).

The teachers referred the resistances to changes and new things to the stability preference of the culture and this cultural feature would challenge teachers and students in teaching and learning argumentation when the designed curriculum was applied into practices.

\section{Institutional challenges}

\section{A. The issue of time for teaching}

Despite their appreciation for the new curriculum design, the teachers asserted that the issue of time could be a barrier to the application of the designed curriculum. According to the teachers, the experimental science lessons were time consuming.

I think these lessons took a lot of time. A current science lesson is taught for around $30 \mathrm{~min}$. If it exceeds the time constraint, it will be assessed by the inspectors as a weak lesson. (T2, Team discussion 6, Source D).

With respect to teaching methods, I think educational inspectors will appreciate these lessons. But with respect to lesson length, I think they will not like the lessons. (T1, Team discussion 6, Source D). 
The teachers considered that the experimental lessons took more time than conventional science lessons, because inquiry and cooperative learning takes more time than listening and reproducing. Moreover, much lesson time was spent dealing with students' questions and the problems that arose during activities and discussions. The teachers anticipated it would be challenging to apply the designed curriculum to primary science education in Vietnam if the time amount for one lesson exceeded 35 min (see Hằng et al., 2015).

\section{B. The assessment of learning results}

According to the teachers, the assessment of learning results for the conventional science curriculum was easier than for the designed curriculum. In the conventional science curriculum, the learning results are mainly assessed based on the student's memorisation of factual knowledge. However, in the teachers' opinions, assessing the students' skills and attitudes as learning results, as emphasised by the designed curriculum, would be more difficult.

It's easier to assess learning results about knowledge. That's what we do now for the conventional science curriculum. Mostly, we assess students' memorisation of knowledge. We can use tests to do it. However, this designed curriculum focuses on developing not only knowledge but also skills and attitudes for students..., but assessing skills and attitudes is very difficult. How to do it? We need to assess it, right? But how to assess it? (T3, Team discussion 8 , Source D).

If they apply the criteria of classroom assessment used in the conventional curriculum to these [experimental] lessons, maybe these lessons will not satisfy. (T2, Team discussion 8, Source D).

The above quotations show that the application of the designed curriculum requires the development of corresponding materials to support teachers in assessing student learning in accordance with the designed curriculum.

\section{The difficulty associated with systemic changes}

The teachers affirmed that the designed curriculum could not be applicable to primary classroom practices in Vietnam without systemic changes.

To apply this curriculum design in practice, there needs to be a change - systemic, consistent, and from top to bottom. (T1, Team discussion 8, Source D).

However, according to the teachers, it was difficult to initiate a systemic change in Vietnam, because of issues related to finance, educational policies, administrations, teacher training, teacher abilities, and so on.

\section{Conclusions and discussion}

This study presented how the Vietnamese teachers in a programme of Teacher PD interacted with a primary science curriculum designed according to a social constructivist perspective and made appropriate for Vietnamese $\mathrm{CHC}$. The study shows changes in teaching attitudes and activities towards a social constructivist approach that the teachers underwent and their perception of the designed science curriculum. The teachers who participated in this PD programme became more openminded, friendly and equitable in interacting with students in the science lessons. In addition, they focused more on (a) encouraging students to engage in inquiry, (b) providing time and space for self-regulated learning, (c) promoting social interactions among students, and (d) seeking elaboration of students' initial responses. 
With these achievements, the designed curriculum is believed to be a first step to address the current problems of the primary science education in Vietnam (Hằng et al. 2015).

With the changes in the Vietnamese teachers' attitudes and teaching activities, this study shows that although teaching is influenced by culture (Nguyen et al. 2005; Hofstede et al. 2010), Vietnamese CHC teachers are highly adaptive. The positive changes in the teachers reinforce the proposition that Vietnamese $\mathrm{CHC}$ could foster the application of a social constructivist approach because it has certain alignments in characteristics with social constructivism, such as the tradition of learning together, the appreciation to peer learning, and the value to collectivity and solidarity (Hằng et al. 2015). The study therefore supports and promotes the application and culturally appropriate adaptation of a social constructivist approach to a $\mathrm{CHC}$ (Hằng et al. 2016). Moreover, given the considerable changes observed in the activities of the $\mathrm{CHC}$ teachers, this study shows that the cultural appropriately adapted and combined spiral programme of Teacher PD (Fig. 1) was effective in facilitating the teachers in their interaction with the designed curriculum and in helping them change attitudes and activities toward a social constructivist approach of science teaching and learning. With these findings, this study strengthens the assertion that "we need to consider redeveloping a curriculum for teacher education more consistent with what we value" (Sosniak 1999; p.200).

This study can be situated within a larger research programme on developing a framework for Teacher PD with three main stages - preparation for teaching, teaching and observing, and reflection - and, as Stolk et al. (2012) recommended, with quite a number of small iterations (nine iterations in this case; Fig. 1). The importance of general strategies, such as collaboration, sharing experiences, co-designing, and reflection are acknowledged by many studies on Teacher PD (Stolk et al. 2012; Vos et al. 2010). This study builds on the knowledge of effective PD programme (Borko 2004) with the establishment of the learning community in which the teachers act as facilitators and critical co-designers (Agung 2013). It also builds on design knowledge of curriculum frameworks and units (Bulte et al. 2006) which was synthesised and adapted to the programme used for Teacher PD (Fig. 1). With the adapted and combined spiral programme, this study reinforces the research results of those former studies.

The teachers in this study perceived that the designed curriculum brings more benefits for students than does the conventional science curriculum (Hằng et $\mathrm{al}$. 2015). They acknowledged that the designed curriculum helped reconceptualise the teaching and learning of science, bringing it closer to a social constructivist approach. Also, the teachers proposed the formulation of teacher activities corresponding with each of the phases of the designed curriculum. With the concrete teaching activities (Table 5) achieved from the heuristic knowledge of the $\mathrm{CHC}$ teachers, this study can provide a response to the call from social constructivist researchers for "teacher presentation of concepts and skills and tighter structuring and scaffolding of students' activities than most social constructivists envision" (Brophy 2006, p.536). Moreover, this study creates the possibility for improving the design with a formulation of the concrete teaching activities that were appropriate for use in practice in a $\mathrm{CHC}$. A curriculum design with concrete teaching activities 
is supported by the claim that the construction and critical discussion of detailed content-specific justifications of teaching-learning sequences, as the core business of science education research, are only effective when firmly grounded in detailed accounts of concrete teaching-learning activities (Klaassen and Kortland 2013). Concrete teaching-learning activities with general considerations that involve theoretical frameworks can be meaningfully clarified, discussed, and compared (Klaassen and Kortland 2013). The design embedded with concrete teaching-learning activities can bridge the gaps between the ideal curriculum and the experiential and attained curriculum (Van den Akker 2003).

The study uncovers major challenges that the Vietnamese teachers perceived to the implementation of the social constructivism-based curriculum in practice. In terms of the challenges for the teachers, three major challenges were mentioned: a) the influences of habits and traditional teaching methods, b) the need for deep understanding of scientific content knowledge, and c) the difficulty of teaching and learning argumentations for Vietnamese primary teachers and students. To a certain extent, these findings of this study are consistent with reports in many cross-cultural studies which described lessons in Asian countries to be traditionally dominated by a teacher-centred, book-centred method and rote memory (Liu and Littlewood 1997) with little emphasis on critical thinking (Couchman 1997); teaching influenced by a $\mathrm{CHC}$ is primarily one-sided in an one-way process: what the teacher announces is right and the students are not entitled to ask about sense and purpose (Chan 1999). In a culture-approach on teaching and learning of science, Ying Tao, Mary Oliver and Grady Venville (2013) also acknowledged the profound influences of Confucian philosophy on science teaching and learning in China, wherein Chinese primary teachers were observed to avoid utilising the recommended group work and memorising science facts was a frequent activity for Chinese primary students, who participated more frequently in passive and closed activities. The researchers believe that it will take time for $\mathrm{CHC}$ teachers to change their habits of traditional teaching when they interact with a newly designed social constructivism-based science curriculum.

The challenges that the Vietnamese $\mathrm{CHC}$ teachers need deep understanding of scientific content knowledge and that the Vietnamese teachers find teaching and learning scientific argumentation difficult align with concerns of researchers and educators about the state of science teaching in many primary classrooms recently. It is asserted that the teachers' lack of confidence to teach science has been largely attributed to their poor background knowledge (Appleton 2007). The findings of this study can reinforce to a certain extent the claim that cooperative learning, in which social constructivist learning is the mainstream, has been applied both in Western culture and in $\mathrm{CHC}$ but the way of applying is different: cooperative learning in a $\mathrm{CHC}$ is in harmony rather than in argumentation or in conflicts (Xiao 2009). This can underpin the proposition that in a face culture like Vietnam, the idea of saving face is very important to people, especially those who, like teachers, are regarded as playing a respectable role in society and perceptions of face influence teachers' behaviours in classrooms (Nguyen 2016). In one hand, this study agree that "Vietnamese educational reformers could perhaps, while paying due reverence to Confucian precepts, also include in teacher 
education programmes an appreciation that expertise in promoting studentcentred learning and co-construction of knowledge by teachers and students are legitimate components of teachers' face that contribute to the acceptance of innovation at the classroom level" (Nguyen 2016, p.11). In the other hand, the study recommends scientific argumentation should be improved through science education to enhance scientific capability in a CHC. In doing this, it needs to balance "nature of science" elements (Abd-El-Khalick and Lederman 2000) and $\mathrm{CHC}$ values in the science curriculum. Also, the study suggests that $\mathrm{CHC}$ teachers need training to have more scientific content knowledge and argument capability so that they can teach science more effectively in primary classroom practices.

The teacher challenges regarding knowledge reflect the main problems that make educational researchers pessimistic about the application of a social constructivist approach to teaching (Nuthall 2002). In our consideration, however, the teacher challenges in applying the designed social constructivism-based curriculum leave room for further development and research. They show that the curriculum design should be improved in order to be a better teaching guideline for teachers to use. In this way, the teaching activities proposed by the Vietnamese $\mathrm{CHC}$ teachers are valuable sources of practical knowledge that can be used. Also, they show that teacher input has a major role within a social constructivist framework that requires an emphasis on PD and teacher education in order to facilitate $\mathrm{CHC}$ teachers in overcoming the challenges more successfully. Further programmes of Teacher PD and teacher education may need to integrate knowledge from different disciplines, diverse procedures, and attitudes (Bulte et al. 2006).

The study shows that the institutional challenges for the application of the designed curriculum were: a) the issue of time, b) the measurement of learning results, and c) the difficulty of a systemic change. To a certain extent, these challenges perceived by the teachers are predictable difficulties with a social constructivist approach (Brophy 2006) and underpin the claim that sustaining a constructivist classroom culture involves dealing with teacher challenges, as well as logistical and political challenges to effective implementation (Airasian and Walsh 1997; Windschitl 1999). The institutional challenges perceived by the teachers reveal that the designed curriculum needs to include certain conditions to make the approach applicable in the educational practice of a $\mathrm{CHC}$. Therefore, to apply the designed curriculum in practice, it needs to accommodate not only the involvement of $\mathrm{CHC}$ teachers as direct actors but also the involvement of educational policy makers, who should primarily consider the coherency of educational policy and practice (Agung 2013) for the application of a science curriculum. Policy makers, stakeholders, and curriculum designers need to coordinate with each other in order to create a facilitative ground that supports the application of a social constructivist approach to primary science education and promotes the growth of an innovative curriculum in a $\mathrm{CHC}$.

\section{Endnotes}

All names of the teachers and students used in this study are pseudonyms. This aims to respect private rights of the research participants. 


\section{Appendix 1}

Table 6 The designed framework of the social constructivism-based curriculum for primary science education in a CHC

\begin{tabular}{|c|c|c|c|c|}
\hline \multirow[t]{2}{*}{ PHASE } & \multirow[t]{2}{*}{ FUNCTION } & \multicolumn{2}{|l|}{ LEARNING SETTING } & \multirow{2}{*}{$\begin{array}{l}\text { EDUCATIONAL } \\
\text { EXPECTATIONS }\end{array}$} \\
\hline & & Activity & Form & \\
\hline Engagement & $\begin{array}{l}\text { A. To provide students } \\
\text { with the motivation to } \\
\text { learn }\end{array}$ & $\begin{array}{l}\text { 1. Doing a small hands-on } \\
\text { task with a relevant } \\
\text { example related to } \\
\text { scientific subject matter } \\
\text { 2. Answering What, How, } \\
\text { and Why questions about } \\
\text { a relevant example related } \\
\text { to scientific subject matter }\end{array}$ & $\begin{array}{l}\text { 1. In small groups } \\
\text { and/or in the class } \\
\text { as a whole }\end{array}$ & $\begin{array}{l}\text { a. Students are interested } \\
\text { in scientific subject matter }\end{array}$ \\
\hline Experience & $\begin{array}{l}\text { B. To evoke attitudes } \\
\text { toward science } \\
\text { C. To acquire procedural } \\
\text { knowledge } \\
\text { D. To acquire conceptual } \\
\text { knowledge } \\
\text { E. To acquire } \\
\text { argumentative skills }\end{array}$ & $\begin{array}{l}\text { 3. Predicting: Observe and } \\
\text { discuss in order to answer } \\
\text { questions: What do you } \\
\text { observe? What will happen } \\
\text { if...? Why do you think so? } \\
\text { 4. Hands-on: Do experiment } \\
\text { and discuss in order to } \\
\text { answer questions: What did } \\
\text { you observe? How can you } \\
\text { explain it? Why do you } \\
\text { think so? } \\
\text { 5. Questioning: Formulate } \\
\text { questions related to } \\
\text { scientific subject matter }\end{array}$ & 2. In small groups & $\begin{array}{l}\text { b. Students are curious } \\
\text { about learning } \\
\text { representative examples } \\
\text { of scientific subject } \\
\text { matter } \\
\text { c. Students are active } \\
\text { in learning about } \\
\text { representative examples } \\
\text { of scientific subject } \\
\text { matter } \\
\text { d. Students use their } \\
\text { intuitive knowledge to } \\
\text { learn about scientific } \\
\text { subject matter } \\
\text { e. Students argue with } \\
\text { each other to attain } \\
\text { consensually agreed } \\
\text { knowledge on } \\
\text { representative examples } \\
\text { of scientific subject } \\
\text { matter }\end{array}$ \\
\hline Exchange & $\begin{array}{l}\text { F. To build on attitudes } \\
\text { toward science } \\
\text { G. To build on procedural } \\
\text { knowledge } \\
\text { H. To build on conceptual } \\
\text { knowledge } \\
\text { I. To build on } \\
\text { argumentative skills }\end{array}$ & $\begin{array}{l}\text { 6. Presenting results to } \\
\text { other groups } \\
\text { 7. Discussing results with } \\
\text { other groups } \\
\text { 8. Answering formulated } \\
\text { questions related to } \\
\text { scientific subject matter }\end{array}$ & $\begin{array}{l}\text { 3. In the class as } \\
\text { a whole and/or } \\
\text { in combined } \\
\text { groups }\end{array}$ & $\begin{array}{l}\text { f. Students are interactive } \\
\text { in learning scientific } \\
\text { subject matter } \\
\text { g. Students argue with } \\
\text { each other to attain } \\
\text { consensually agreed } \\
\text { knowledge on scientific } \\
\text { subject matter }\end{array}$ \\
\hline Follow-up & $\begin{array}{l}\text { J. To acquire cognitive } \\
\text { flexibility } \\
\text { K. To further learning } \\
\text { motivation }\end{array}$ & $\begin{array}{l}\text { 9. Providing answers } \\
\text { and/or solutions for } \\
\text { questions and/or } \\
\text { problems related to } \\
\text { scientific subject matter }\end{array}$ & $\begin{array}{l}\text { 4. In the class as } \\
\text { a whole }\end{array}$ & $\begin{array}{l}\text { h. Students can provide } \\
\text { appropriate answers and/ } \\
\text { or solutions on applying } \\
\text { attained knowledge } \\
\text { i. Students show their } \\
\text { desire to learn more } \\
\text { about scientific subject } \\
\text { matter }\end{array}$ \\
\hline
\end{tabular}




\section{Appendix 2}

Table 7 The designs of exemplary curriculum units

\begin{tabular}{|c|c|c|c|}
\hline Phase & Unit Air Pressure & Unit Plant Roots & Unit $\mathrm{CO}_{2}$ Reactions \\
\hline Engagement & $\begin{array}{l}\text { 1. Answering: What will happen } \\
\text { if we blow breath into the } \\
\text { inflated balloon? Why do you } \\
\text { think so? What will happen if } \\
\text { the inflated balloon is released } \\
\text { at once? Why do you think so? } \\
\text { 2. Blowing breath into the inflated } \\
\text { balloon and releasing it, and } \\
\text { answering: What happened? } \\
\text { How can you explain what was } \\
\text { observed? }\end{array}$ & $\begin{array}{l}\text { 1. Drawing a complete plant } \\
\text { 2. Answering: What did you } \\
\text { draw? Why did you draw the } \\
\text { plant root like that? How did } \\
\text { you know it? }\end{array}$ & $\begin{array}{l}\text { 1. Answering: What will happen if } \\
\text { we blow breath through a straw } \\
\text { into a water bottle? Why do you } \\
\text { think so? } \\
\text { 2. Blowing breath through a } \\
\text { straw into a water bottle and } \\
\text { answering: What happened? } \\
\text { How can you explain what was } \\
\text { observed? }\end{array}$ \\
\hline Experience & $\begin{array}{l}\text { 3. Predicting (Exercise 1): Connect } \\
\text { two cylinders with a plastic tube. } \\
\text { Discuss with your peers and } \\
\text { answer the following questions: } \\
\text { a. What will happen if one cylinder } \\
\text { is pressed down? } \\
\text { b. Why do you think so? } \\
\text { 4. Hands-on (Exercise 2): Press one } \\
\text { of the connected cylinders down. } \\
\text { Discuss in your group answers to } \\
\text { the following questions: } \\
\text { a. What did you observe? } \\
\text { b. How can you explain what was } \\
\text { observed? } \\
\text { 5. Questioning (Exercise 3): Write } \\
\text { down questions or ideas related } \\
\text { to the subject matter that you } \\
\text { want to discuss. }\end{array}$ & $\begin{array}{l}\text { 3. Predicting (Exercise 1): } \\
\text { Choose a wild plant in the } \\
\text { school garden to observe. } \\
\text { Discuss in the group the } \\
\text { answers to the following } \\
\text { questions: } \\
\text { a. What do you think the plant } \\
\text { root looks like? Draw it. } \\
\text { b. Why do you think so? } \\
\text { 4. Hands-on (Exercise 2): } \\
\text { Pull out the wild plant in the } \\
\text { school garden. Discuss in the } \\
\text { group the answers to the } \\
\text { following questions: } \\
\text { a. What does the plant root look } \\
\text { like? Draw it. } \\
\text { b. Why does this plant have a } \\
\text { root like that? } \\
\text { c. What are the functions of the } \\
\text { plant root? Why do you think so? } \\
\text { 5. Questioning (Exercise 3): Write } \\
\text { down questions or ideas related } \\
\text { to the subject matter that you } \\
\text { want to discuss. }\end{array}$ & $\begin{array}{l}\text { 3. Predicting (Exercise 1): Given a } \\
\text { Coca Cola bottle and some Mentos. } \\
\text { Discuss in your group the answers } \\
\text { to the following questions: } \\
\text { a. What will happen if all the Mentos } \\
\text { are dropped into the coke bottle? } \\
\text { b. Why do you think so? } \\
\text { 4. Hands-on (Exercise 2): Drop all } \\
\text { the Mentos into the coke bottle. } \\
\text { Discuss in your group the answers } \\
\text { to the following questions: } \\
\text { a. What did you observe? } \\
\text { b. Why did it happen? } \\
\text { 5. Questioning (Exercise } 3 \text { ): Write } \\
\text { down questions or ideas related } \\
\text { to the subject matter that you want } \\
\text { to discuss }\end{array}$ \\
\hline Exchange & $\begin{array}{l}\text { 6. Presenting results to other } \\
\text { groups } \\
\text { 7. Discussing results with other } \\
\text { groups } \\
\text { 8. Answering formulated } \\
\text { questions related to subject } \\
\text { matter }\end{array}$ & $\begin{array}{l}\text { 6. Presenting results to other } \\
\text { groups } \\
\text { 7. Discussing results with other } \\
\text { groups } \\
\text { 8. Answering formulated } \\
\text { questions related to subject } \\
\text { matter }\end{array}$ & $\begin{array}{l}\text { 6. Presenting results to other } \\
\text { groups } \\
\text { 7. Discussing results with other } \\
\text { groups } \\
8 \text {. Answering formulated } \\
\text { questions related to subject matter }\end{array}$ \\
\hline Follow-up & $\begin{array}{l}\text { 9. Answering the questions: } \\
\text { What did you learn from the } \\
\text { lesson today? Can you provide } \\
\text { some examples related to air } \\
\text { pressure and explain why you } \\
\text { think what you do about them? }\end{array}$ & $\begin{array}{l}\text { 9. a. Answering questions: What } \\
\text { did you learn from the lesson } \\
\text { today? Can you provide some } \\
\text { examples of root types and explain } \\
\text { why you think those plants have } \\
\text { such root types? } \\
\text { 9.b. Determining type of root for } \\
\text { some plants }\end{array}$ & $\begin{array}{l}\text { 9. Answering questions: What did } \\
\text { you learn from the lesson today? } \\
\text { Can you provide some examples of } \\
\text { carbon dioxide reaction and explain } \\
\text { why you think what you do about } \\
\text { them? }\end{array}$ \\
\hline
\end{tabular}

\section{Acknowledgements}

The authors would like to thank the teachers Đỗ Thị Thanh Vân, Nguyễn Thu Hương, and Nguyễn Thị Ánh at Đông Ngàn primary school in Vietnam for their enthusiastic and whole-hearted participation in this research project.

\section{Authors' Contributions}

N.V.T. Hằng made substantial contributions to conception, acquisition of data, analysis and interpretation of data, drafted the article, and revised it critically. A. M. W. Bulte and A. Pilot supervised the research implementation, provided arguments and suggestions, and revised the article. All of the three authors read and approved the final manuscript.

\section{Authors information}

Ngô Vũ Thu Hằng has been a teacher trainer and a researcher at Hanoi National University of Education in Vietnam for more than ten years. She received her doctoral degree in Education from Utrecht University, The Netherlands. Her research area focuses on curriculum development for primary school education. She is also interested in how culture influences on education. 
Astrid M. W. Bulte is an experienced science educator and researcher at the Freudenthal Institute for Science and Mathematics Education (Flsme) where she works as a team leader for the chemical education group (Science Faculty). Her studies focus on context-based science education, the professional development of teachers, and macro - micro thinking in (life) science education. She is an author and coauthor of numerous articles in science education. In addition, she has been working as a supervisor and a promoter for doctoral studies.

Albert Pilot is known internationally for his research in science education, particularly in the fields of designbased research approach, context-based education, and chemistry education. He is an author and coauthor of numerous articles and books on science education. In addition, he has been working as a supervisor and a promoter for many doctoral studies.

\section{Competing interests}

We declare that we have no competing interest.

\section{Publisher's Note}

Springer Nature remains neutral with regard to jurisdictional claims in published maps and institutional affiliations.

\section{Author details}

${ }^{1}$ Hanoi National University of Education, 136 Xuan Thuy, Cau Giay, Hanoi, Vietnam. ${ }^{2}$ Freudenthal Institute for Science and Mathematics Education, Utrecht University, Princetonplein 5, 3584 CC Utrecht, The Netherlands.

Received: 10 March 2017 Accepted: 25 June 2017

Published online: 21 July 2017

\section{References}

Abd-El-Khalick, F., \& Lederman, N. G. (2000). Improving science teachers' conceptions of nature of science: A critical review of the literature.International. Journal of Science Education, 22(7), 665-701.

Agung, S. (2013).Facilitating professional development of Madrasah chemistry teachers.Doctoral dissertation. Utrecht University, Netherlands.

Airasian, P., \& Walsh, M. (1997). Constructivist cautions. Phi Delta Kappan, 78, 444-449.

Anderson, R. D. (1996). Study of curriculum reform. (volume I of the final report of research conducted under contract no. RR91182001 with the Office of Educational Research and Improvement, U.S. Department of Education). Washington, DC: U.S. Government Printing Office.

Beck, C., \& Kosnik, C. (2006).Innovations in teacher education - A social constructivist approach. Albany, NY: State University of New York Press.

Berthrong, J. H., \& Berthrong, E. N. (2000). Confucianism: A short introduction. Oxford: Oneworld.

Borko, J. (2004). Professional development and teacher learning: Mapping the terrain. Educational Researcher, 33(8), 3-15.

Brooks, J., \& Brooks, M. (1993).In search of understanding: The case for constructivist classrooms. Alexandria, VA: Association for Supervision and Curriculum Development.

Brophy, J. (2006). Graham Nuthall and social constructivist teaching: Research-based cautions and qualifications. Teaching and Teacher Education, 22, 529-537.

Bulte, A. M. W., Westbroek, H. B., De Jong, O., \& Pilot, A. (2006). A research approach to designing chemistry education using authentic practices as contexts.International. Journal of Science Education, 28(9), 1063-1086.

Chan, S. (1999). The Chinese learning - A question of style. Education and Training, 41(6/7), 294-304. doi:10.1108/ 00400919910285345.

Clarke, D., \& Hollingsworth, H. (2002). Elaborating a model of teacher professional growth. Teaching and Teacher Education, 18(8), 947-967.

Coenders, F., Terlouw, C., \& Dijkstra, S. (2008). Assessing teachers beliefs to facilitate the transition to a new chemistry curriculum: What do the teachers want? Journal of Science Education, 19(4), 317-335.

Coll, R. K., \& Taylor, N. (2012).An international perspective on science curriculum development and implementation. In B. J. Fraser, K. G. Tobin, \& C. J. McRobbie (Eds.), Second international handbook of science education (Vol. II, pp. 771-782). Dordrecht, Netherlands: Springer.

Cotton, D. R. E. (2006). Implementing curriculum guidance on environmental education: The importance of teachers' beliefs. Journal of Curriculum Studies, 38, 67-83.

Couchman, J. (1997). Making sense: Cross-cultural variation in the organisation of academic texts by Taiwanese and Australian undergraduate students. In Z. Golebiowski \& H. Borland (Eds.), Academic communication across disciplines and cultures (pp. 64-76). Melbourne, Australia: Victoria University of Technology.

Creswell, J. W. (2009). Research design: Qualitative, quantitative, and mixed methods approaches (3rd ed.). Thousand Oaks, CA: Sage Publications.

Đạm, Q. (1994). Nho giáo xưa và nay [Confucianism: Past and present]. Hanoi, Vietnam: Culture Publisher.

Dewey, J. (1933). How we think: A restatement of the relation of reflective thinking to the educative process. Chicago, IL: Henry Regnery.

Duffee, L., \& Aikenhead, G. (1992). Curriculum change, student evaluation, and teacher practical knowledge. Science Education, 76(5), 493-506.

Fullan, M. G. (1991). The new meaning of educational change $\left(2^{\text {nd }}\right.$ ed.). New York, NY: Teachers College Press.

Gess-Newsome, J. (1999). Pedagogical content knowledge: An introduction and orientation. In J. Gess-Newsome \& N. G. Lederman (Eds.), Examining pedagogical content knowledge (pp.3-17). Dordrecht, Netherlands: Kluwer Academic Publishers.

Glatthorn, A. (1995). Teacher development.In L. Anderson (Ed.), International encyclopedia of teaching and teacher education (2nd ed., pp.41-45). London, UK: Pergamon Press. 
Guskey, T. R. (2002). Professional development and teacher change. Teachers and Teaching: Theory and Practice, 8(3/4), 381-391.

Hand, B., Treagust, D. F., \& Vance, K. (1997). Student perceptions of the social constructivist classroom.Science. Education, 81(5), 561-575.

Hằng, N. V. T., Meijer, M., Bulte, A., \& Pilot, A. (2015). The implementation of a social constructivist approach in primary science education in Confucian heritage culture: the case of Vietnam. Cultural Studies of Science Education, 10(3), 665-693. doi:10.1007/s11422-014-9634-8.

Hằng, N. V. T., Meijer, M., Bulte, A. \& Pilot, A. (2016). Designing a primary science curriculum in a globalising world: how do social constructivism and Confucian heritage culture meet?, Cultural Studies of Science Education, p.1-22, doi:10.1007/s11422-015-9696-.

Hoan, Đ. Đ. (2002). Một số vấn đề cơ bản của chương trình tiểu học mới [Some basic issues of the new primary curricula]. Hanoi, Vietnam: Education Publisher.

Hofstede, G., Hofstede, G. J., \& Minkov, M. (2010).Cultures and organizations: Software of the mind: Intercultural cooperation and its importance for survival( $3^{\text {rd }}$ ed.). New York, NY: McGraw-Hill.

Huang, Y. S., \& Asghar, A. (2016). Science education reform in Confucian learning cultures: policymakers' perspectives on policy and practice in Taiwan, Asia-Pacific Science Education, 62(3), doi:10.1186/s41029-016-0010-8.

Klaassen, K., \& Kortland, K. (2013). The role and nature of theory in design research. In Paper presented at the $13^{\text {th }}$ ESERA conference: Science education research for evidence-based teaching and coherence in learning. Cyprus: Cyprus University.

Le Cornu, R., \& Peters, J. (2005). Towards constructivist classrooms: The role of the reflective teacher. Journal of Educational Enquiry, 6(1), 50-64.

Lee, J. K. F. (2008). A Hong Kong case of lesson study: Benefits and concerns. Teaching and Teacher Education, 24(5), 1115-1124. doi:10.1016/j.tate.2007.10.007.

Liu, N. F., \& Littlewood, W. (1997). Why do many students appear reluctant to participate in classroom learning discourse? System, 25(3), 371-384. doi:10.1016/S0346-251X(97)00029-8.

Loughran, J., Mulhall, P., \& Berry, A. (2004). In search of pedagogical content knowledge in science: Developing ways of articulating and documenting professional practice. Journal of Research in Science Teaching, 41(4), 370-391.

Nguyen, M., Terlouw, C., \& Pilot, A. (2005). Cooperative Learning vs Confucian Heritage Culture's Collectivism: confrontation to reveal some cultural conflicts and mismatch. Asia Europe Journal, 3(3), 403-419.

Nguyen, T. Q. T. (2016). Maintaining teachers' face in the context of change: Results from a study of Vietnamese college lecturers' perceptions of face. Teachers and Teaching theory and practice. http://dx.doi.org/10.1080/13540602.2016. 1203779

Nuthall, G. (2002). Social constructivist teaching and the shaping of students' knowledge and thinking. In J. Brophy (Ed.), Social constructivist teaching: Affordances and constraints (pp. 43-79). New York, NY: Elsevier.

Örtenblad, A., Babur, M., \& Kumari, R. (2012). Learning in Asia. Asia Pacific Journal of Education, 32(2), 131-136.

Sosniak, L. A. (1999). Professional and subject matter knowledge for teacher education. In G. A. Griffin (Ed.), The education of teachers: $98^{\text {th }}$ NSSE yearbook, part I (pp.185-204). Chicago, IL: National Society for the Study of Education.

Stolk, M. J., Bulte, A. M. W., De Jong, O., \& Pilot, A. (2011).Exploring a framework for professional development in curriculum innovation: Empowering teachers for designing context-based chemistry education.Research in Science Education, 41, 369-388

Stolk, M. J., Bulte, A. M. W., De Jong, O., \& Pilot, A. (2012). Evaluating a professional development framework to empower chemistry teachers to design context-based education.International. Journal of Science Education, $34(10), 1487-1508$.

Tao, Y., Oliver, M., \& Venville, G. (2013). A comparison of approaches to the teaching and learning of science in Chinese and Australian elementary classrooms: Cultural and socioeconomic complexities. Journal of Research in Science Teaching, 50(1), 33-61.

Thêm, T. N. (1997). Tim về bản sắc văn hóa Việt Nam [Research on Vietnamese cultural distinctions]. Ho Chi Minh, Vietnam: Ho Chi Minh Publisher.

Van den Akker, J. J. H. (2003). Curriculum perspectives: An introduction. In J. J. H. Van den Akker, W. Kuiper, \& U. Hameyer (Eds.), Curriculum landscape and trends (pp.1-10). Dordrecht, Netherlands: Kluwer Academic Publisher.

Van Driel, J. H., Verloop, N., \& De Vos, W. (1998). Developing science teachers' pedagogical content knowledge. Journal of Research in Science Teaching, 35(6), 673-695.

Vos, M. A. J., Taconis, R., Jochems, W. M. G., \& Pilot, A. (2010). Teachers implementing context-based teaching materials: A framework for case-analysis in chemistry. Chemistry Educational Research and Practice, 11, 189-206.

Vygotsky, L. (1978). Mind in society: The development of higher psychological processes. Cambridge, MA: Harvard University Press.

Watson, J. (2001). Social constructivism in the classroom. Support for Learning, 16(3), 140-147.

Windschitl, M. (1999). The challenges of sustaining a constructivist classroom culture.Phi. Delta Kappan, 80(10), 751-755.

Xiao, L. (2009). What can we learn from a learning needs analysis of Chinese English majors in a university context? Asian EFL Journal, 8(4), 74-79. 